\title{
Nesnel Bilgi Mi, İnşa Olarak Bilgi Mi?: Küresel Yaşlanma, Eğitim-Geliştirme İlişkisi Üzerine Bir Tartışma
}

\section{Objective Knowledge or Socially Constructed Knowledge: A Debate on the Relationship Between Global Ageing and Training-Development Area}

\author{
Doç. Dr. Fuat Man ${ }^{1}$ - Arş. Gör. Canan Yılmaz²
}

Başvuru Tarihi: 17.09.2018

Kabul Tarihi: 28.05.2019

\section{Öz}

Bu çalışma, klasik modernitenin 'nesnel bilgi' iddialarının karşısında postmodernitenin 'bir inşa olarak bilgi' yaklaşımına dayanarak belirli alanların, cari ihtiyaçlara bir cevap olarak doğduğunu ya da bu alanlardaki söylemlerin cari ihtiyaçlara göre icat edildiğini, evirildiğini ya da değiştiğini öne sürmektedir. Çalışma, bu iddiasını eğitim ve geliştirme alanının gelişimi üzerinde temellendirmektedir. Bu temellendirmeyi, akışkan bir dünyada küresel yaşlanmanın beraberinde getirmiş olduğu sorunların bir çözümü olarak eğitim ve geliştirme alanının rolüne odaklanarak yapmaktadır. Çalışma öncelikle postmodernitenin bilgi ile olan ilişkisini ortaya koymaktadır. Burada postmodernitenin mutlak bilgiye karşı mesafeli duruşu ve bilgiyi sosyal bir inşa olarak ele alan yaklaşım gösterilmektedir. Çalışma daha sonra küresel yaşlanma meselesini verilerle ele alıp son kısımda ise bu hususların eğitim ve geliştirme alanı için ne anlama geldiğini göstermektedir.

Anahtar Kelimeler: Postmodernite-Bilgi İlişkisi, Küresel Yaşlanma, Eğitim ve Geliştirme

\begin{abstract}
This paper argues that some areas or these areas' discourses are emerging or have been invented from the current needs, based not on the classical modernitiy's 'objective knowledge' claims but on postmodernity's 'knowledge as a construction' approach. The paper grounds its argument on the evolution of training and development area. The paper justifies its argument by focusing on a role of training and development area as a solution for the problems arising from global ageing in a liquid world. With that connection, the paper begins with a section on postmodernity-knowledge relationship and then presents the global ageing issue with some general figures. And the last section tries to demonstrate what all these issues mean for training and development field.
\end{abstract}

Keywords: Postmodernity-Knowledge Relationship, Global Ageing, Training and Development

${ }^{1}$ Sakarya Üniversitesi İşletme Fakültesi, fuatman@gmail.com, ORCID: 0000-0002-7135-8320

${ }^{2}$ Sakarya Üniversitesi İşletme Fakültesi, cananyilmaz@sakarya.edu.tr, ORCID: 0000-0002-7135-8320 


\section{Giriş}

$\mathrm{Bu}$ makalenin başlı̆ğ ve dolayısıyla ortaya koymaya çalıştı̆̆ tartışma, birkaç eğilimden beslenmektedir: Öncelikle gerçekten de verileri aşağıda sunularak ortaya konulacak küresel yaşlanma denen nesnel bir gerçeklik var karşımızda. İkincisi, özellikle günümüz örgütlerinin kayıtsız kalamayacakları çok boyutlu bir değişim dalgası yaşanmakta ve bu dalga her türlü örgütü, kendisini sıklıkla "güncellemek" zorunda bırakmaktadır, aksi takdirde yoğun rekabet ortamında geride kalmaları hatta faaliyetlerini sonlandırmak zorunda kalmaları kaçınılmaz görünmektedir. Bu kapsamda çalışmanın amacı; bu iki değişken arasındaki ilişkinin ne olduğu üzerinden bir tartışma yürütmektir. Şöyle ki, bu çalışma her ne kadar bir "postmodernizm" savunusu amacında değilse de postmodernizmin bilgiye yönelik yaklaşımının eğitim ve geliştirme alanındaki bir örneğini ortaya koyma çabasındadır.

Bilindiği gibi postmodernite, "nesnel bilgi” ya da "hakikat" iddialarına karşı genelde mesafelidir ve bilgiye yaklaşımı daha çok onun sosyal olarak inşa edildiğine yöneliktir. Özellikle son zamanlarda demografik alanda yaşanan somut gelişmeler -bu çalışma açısından, küresel yaşlanma- eğitim ve geliştirme alanında da bir söylem kaymasına ya da yeni bir söylemin ortaya çıkmasına yol açmıştır. Söz konusu olan kısaca, öğrenmeye kapalı, yeniliklere karşı katı, geleneksel metotlara aşina yaşlıdan; daha esnek, tecrübelerin onu avantajlı kıldığı bir yaşlı söylemine doğru kaymadır. İşte bu noktada eğitim ve geliştirme alanı bu söylemin gerçekleştiği bir zemin olarak ortaya çıkmaktadır. Başka bir şekilde ifade edecek olursak, postmodernite, nesnel bir bilgiden ziyade inşa olarak bilgiyle ilgilenmekte ve bu belirli kabullerin zaman ve mekan açısından hem dikey hem de yatay bir biçimde değişebileceğini ima etmektedir. Kısacası bir toplumda belirli kabuller bir müddet sonra terkedilebilir ve yerlerine yenileri konulabilir ya da aynı zaman dilimi içinde farklı toplumlarda farklı 'gerçeklikler' söz konusu olabilir.

Bu çalışmada gösterilmeye çalışılan veya iddia edilen şey, çağımızın çok hızlı bir değişim dalgası içinde olduğu, bu dalgaya eşlik eden bir hususun da küresel yaşlanma meselesi olduğu ve dolayısıyla bu iki unsurun birlikte, gereksinim duyulan yeni bir söylem geliştirdiğine ya da icat ettiğine yöneliktir. Bu çalışma bu söylemi, 'eğitim ve geliştirme' çerçevesinde ele almayı amaçlamaktadır. Çalışmanın ilk kısmında postmodernizmin bilgiye yönelik yaklaşımını, postmodernizmin bilgiyi nesnel bir gerçeklikten ziyade sosyal bir inşa olarak ele aldığını ortaya koymaya çalışmaktadır. İkinci kısımda, küresel yaşlanma meselesi ele alınmaktadır. Son kısımda ise bu durumun, yani dünya nüfusunun genel olarak yaşlanmasının özellikle emek piyasası bağlamında ne tür sonuçlar doğurduğunu ve bu sonuçların eğitim ve geliştirme alanına ne tür roller yüklediğini ortaya koymaya çalışılmaktadır.

\section{Postmodernizm-Bilgi ílişkisi}

Bilgi kavramı insanlık tarihi kadar eski bir geçmişe sahiptir. Tarım devriminden önceki avcıtoplayıcı toplumlarda insan sadece hammadde ve gıda için toplayıcılık yapmıyor aynı zamanda Harari (2017, s.60)'nin de belirttiği gibi "bilgi” de topluyordu. İnsanların hayatta kalabilmek için; bölgelerinin haritası, hayvanların alışkanlıkları, bitkilerin büyüme biçimleri, gıdaların besleyicilik-hastalık gibi özellikleri, fırtına başlangıç işaretleri gibi bilgileri toplamaları 
gerekmekteydi. Bu dönemde bilgi hayatta kalmak için toplanan bir şeyi ifade etmektedir. Sonraki dönemlerde bilgi ile ilgili çeşitli bakış açılarına uygun tanımlamalar yapılmıştır. Özellikle 19.yüzyıl da modernizm ve 1980'li yıllardan itibaren etkili olan postmodernizm açısından bilgi kavramının tanımları eğitim ve geliştirme açısından önem arz etmektedir. ${ }^{3}$

Modernizm 19.yüzyılda Batı dünyasında egemen hale gelen dünya görüşünü ifade etmektedir. Modernizm Sarıbay (2001, s.4-5)'ın da belirttiği gibi; modern kapitalist-endüstriyel devletin gelişimine paralel olarak geleneksel düzenin zıddı ilerlemenin, ekonomik ve idari rasyonalizasyonun ve sosyal dünyanın farklılaşmasının vuku bulduğu bir durumu ifade etmektedir. Giddens (2016, s.9)'ın ifadesiyle modernizm; sosyolojik açıdan başlangıçta Avrupa'da ortaya çıkmış, daha sonra tüm dünyayı etkilemiş bir örgütlenme ve yaşam biçimi olarak tanımlanmaktadır. Pozitivizm, akılcılık, özerklik ve bilginin evrenselliği ilkelerini benimseyen modernizmin bilgi anlayışı tarafsız ve nesnel olmayı gerektirmektedir. Temelde modernizm sistematiklik, düzenlilik ve genellemelerden bahsetmekte ve bilginin üretilemeyeceği, doğada var olduğu; deney ve gözlemlerle keşfedileceği düşüncelerine dayanmaktadır. Merriam (2015, s.8)'a göre bu bakış açısındaki katılık postmodernizmi ortaya çıkarmıştır.

Toynbee, 1974 yılında Batı uygarlığının İkinci Dünya Savaşı’ndan sonra girdiği yeni dönemi postmodernlik olarak ifade etmektedir (Sarıbay, 2001, s.6). Postmodernizm post ön eki ile modernizmi aşmak veya ona üstün gelmek için toplumun ne olduğunu, olacağını veya olması gerektiğini belirlemeye çalışmaktadır. Kısaca post eki önceki argümanlardan farklı yeni argümanlar üretildiğini ifade ederek modernizmden farkını ortaya koymaktadır. Postmodernizm 1980'lerde radikal teori ve politikanın zayıflaması; imalat sanayinin Batının dışına, İkinci ve Üçüncü Dünya ülkelerine kaydırılması; görünüşe bakılırsa durdurulamayan tüketimciliğin küresel düzeyde yayılması; yeni bilişim ve teknolojinin geliştirilmesi kadar yeni kimlik politika biçimlerinin oluşumunun da ortaya çıkardığ 1 bir sonuçtur (Elliot, 2017, s.292). Modernizm ile temel farkı; Modernizm genellemeler yapmak amacındayken, postmodernizmin sorunsallaştırma amacı gütmesinden kaynaklanmaktadır. Postmodernizm; genellemeleri reddetmesi ve özneler arası etkileşim vurgusu ile modernizmin değerlerini temelden sarsmaktadir.

Genel olarak postmodernizm; bir takım ortak özelliklere sahip teori veya perspektiflerin bir ailesi olarak değerlendirilebilir ( Slife ve Williams, 1995). Lytord (2013, s.11) postmodernizmi "meta anlatılara inanmamak" olarak tanımlayıp özelliklerinin “aydınlanma, hakikat, özgürlük, adalet ve akıl gibi büyük anlatıları reddetmeyi gerektirdiğini” ifade etmektedir. Yine Calinicos (2001, s.16) da postmodernizmi; "büyük anlatılara yönelik inanmazlık" olarak tanımlamaktadır. Postmodernliğin en önemli yanı Wallace ve Wolf (2012, s.549)'un da ifade ettiği gibi bilimsel ölçüyü ve bir tek tutarlı akılsallık olabileceğini veya gerçeklerin kesinlikle gözlemlenebilecek ya da anlaşılabilecek şekilde bir yapıya sahip olduğunu reddetmesidir.

\footnotetext{
3 Sosyal teoride 'postmodernizm'in üzerinde uzlaşılmış bir tabir olmadığını vurgulamak gerekiyor. Nitelemenin kendisi üzerindeki tartışmalar bu çalıșmanın odağında yer almamaktadır. Burada çeșitli sebeplerle moderniteden farklı bir dönem ve zihniyeti ima eden bir kavram olarak 'postmodernizm' kavramının kullanımı tercih edilmiştir. Bu tercih elbette tartışmaya açıktır ancak biz daha çok bu etiket altına konulan bakış açısının bilgiye yönelik yaklaşımını konu ediniyoruz.
} 
Bunun yerine postmodernler Green (1994: 70)'in de ifade ettiği gibi gerçekliğin heterojen ve çoğulcu tabiatını konu edinerek insan bilincinin dengesiz ve değişken yapısını vurgulamaktadır. Temel anlayışı; bilgi taleplerinin sınıf, cinsiyet, ırk gibi bağlantılarının çoklu perspektifini ortaya koymaktır. Spicer (2005, s.671)'ın ifadesiyle postmodernizm; değerlerin, kültürlerin, geleneklerin ve yaşam tarzlarının farklılıkları üzerine kuruludur. Bu koşullar farklı söylemlerin önemini ve evrensel yapıları kapsamaktadır. Aynı zamanda metinlerin dil açısından "yorumlanmasını", okunup yazılmasını ve hakimiyet, zıtlık, tutarsılık, çelişki gibi gizli hiyerarşilerin gün yüzüne çıkarılıp sınanması ihtiyacını kapsamaktadır (Bloland, 1995; Clarke, 2005; Stringer, 1993). Postmodernizm bilgi kavramını da farklı şekilde ele almaktadır.

Postmodern bilginin iki yüzü vardır. Birlik, evrenselleşme ve bütünlük savında modern söylemin bozgunu, özü gereği hoşgörü ve çok sesliliğin bir güvencesidir (Mattelart, 2012, s.75). İçerisinde bulunduğumuz dönemde yapılan bilgi tartışmalarının sonucunda bilimsel bilginin dışındaki anlatılar; toplumsal kurumlara meşruluk kazandırırken bir yandan da bu kurumları bütünleştirmeyi sağlamaktadır. Sonuçta anlatılar olması gerekenin sınırlarını belirleyerek yapılması gerekenleri ve yapılmaması gerekenleri ayırt etmeyi sağlamaktadır. Postmodernizm literatürünün önemli figürlerinden Foucault (2017)'nun ifadesiyle bilgi; iktidarın üstünlük kurmasının, güç gösterisinin olmazsa olmazı ve iktidar ilişkisini meşrulaştırma aracıdır.

Postmodernizm bilginin mutlak yerine göreceli olduğunu ifade ederken bir yandan da Patton (2002, s.93)'un da belirttiği gibi "deneysel kanıtlar kullanılırken akla yatkın ve yatkın olmayan iddiaları birbirinden ayırt etmenin de mümkün olduğunu” vurgulamaktadır. Postmodernizm bilginin benzersiz olduğunu ve çok farklı formlar alabileceğini iddia etmektedir. Lyotard (2013, s.4)'un da belirttiği gibi postmodernizm bilgiyi "bir tür söylem” olarak görür. Bu çerçevede en geniş ifadesiyle bilgi; "herhangi bir gerçekliğin ya da bir başka ifadeyle evrenin olgularının birebir temsili” olarak tanımlanabilir (Şaylan, 2006, s.160-161).

Buradaki tartışma bağlamında, postmodernistlerin 'nesnel', 'genel geçer' bilgiye mesafeli olduklarını ve gerçekliğin aslında sosyal olarak inşa edildiğine yönelik bir bakış açısı paylaştıklarını söylemek mümkündür. Bu ise 'hakikat'in ya da 'gerçekliğin' zamanın ruhuna uygun bir biçimde sosyal olarak üretildiği anlamına gelmektedir. Bunun eğitim ve geliştirme açısından ne anlama geldiği ise ilerleyen alt bölümlerde ele alınacaktır.

\section{Küresel Yaşlanma}

Yirmi birinci yüzyılın en dikkat çekici özelliklerinden birisi dünya genelinde yaşlı nüfus sayısındaki artıştır. Dünyada yaşlı nüfus artış hızı (\%2.1) genel nüfus artış hızından (\%1.2) fazladır. Yaşlı kişilerin nüfus içindeki paylarının artışı kısaca nüfusun yaşlanmasını ifade etmektedir. Nüfusun yaşlanması; bir nüfusun yaş yapısının değişerek, o nüfustaki çocukların ve gençlerin payının azalması ve yaşlı insanların (60 yaş üstü veya 65 yaş üstü) ${ }^{4}$ payının göreceli olarak artmasıdır (DPT, 2007). Buna küresel yaşlanma ismi verilmektedir. Küresel yaşlanma ile nüfusun yaş grupları yapılanması şekil değiştirmekte, ölüm ve doğum da azalma ile birlikte

\footnotetext{
Yaşlı tanımının yaş aralığı ülkelere göre değişmektedir. Örneğin Birleşmiş Milletler Yaşlılık döneminin kendi içinde birtakım farklılıklar içermesi
} sebebiyle 65-74 yaş arası genç yaşlı, 75-84 yaş arası yaşlı, 85 yaş ve üzeri dönemi ise ileri yaşlı olarak adlandırmaktadır. 
doğumdan sonra beklenen yaşam süresinde artış olmakta, çocuk ve gençlerin nüfus içindeki oranı azalırken yaşlıların yüzdesi artmaktadır (Sardon, 2006; United Nations, 2015). TÜİK (2017) raporunda yaşlı nüfus oranının son beş yılda 5 milyon 682 bin kişi iken 6 milyon 651 bin 503 sayısına ulaşarak \%17,1 arttığı belirtilmiştir. Dünya nüfusunun 2016 yılında \%8,7'sini yaşlı nüfus oluşturmuştur. En yüksek yaşlı nüfus oranına sahip ilk üç ülke sırasıyla \%31,3 ile Monako, \%27,3 ile Japonya ve \%21,8 ile Almanya'dır. Aşağıda Tablo 1'de yaşlı nüfusun genel nüfusa oranı ve gelecekteki oran tahmini verilmiştir.

Tablo1. Yaşlı Nüfusun Genel Nüfusa Oranı (\%)

\begin{tabular}{|c|c|c|}
\hline ÜLKE & 2015 & 2050 \\
\hline Hindistan & 5 & 13 \\
\hline Endonezya & 5 & 14 \\
\hline Malezya & 6 & 17 \\
\hline Meksika & 6 & 19 \\
\hline Rusya & 13 & 21 \\
\hline Amerika & 15 & 22 \\
\hline Brezilya & 8 & 23 \\
\hline İngiltere & 18 & 25 \\
\hline Şili & 11 & 26 \\
\hline Fransa & 19 & 26 \\
\hline Kanada & 16 & 26 \\
\hline Çin & 10 & 28 \\
\hline Tayland & 10 & 30 \\
\hline Almanya & 21 & 32 \\
\hline Hong Kong & 15 & 35 \\
\hline İtalya & 22 & 35 \\
\hline Güney Kore & 13 & 35 \\
\hline Japonya & 26 & 36 \\
\hline
\end{tabular}

${ }^{\star}$ United Nations (2015), World Population Prospects: The 2015 Revision.

Tablo 1'de 65 yaş ve üzerindeki yaşlı nüfusun 2015-2050 yılları arasındaki nüfusa oranı verilmiştir. Güney Kore \%22'lik bir oranla 2050 yılında genel nüfusa göre yaşlı nüfusun en çok olması beklenen ülkedir. Onu \%20'lik oranla Hong-Kong ve Tayland ardından \%18 ile Çin takip etmektedir. United Nations (2015) raporuna göre 2015-2030 yılları arasında dünyadaki 60 yaş 
ve üstü nüfusun, 901 milyondan 1,4 milyara çıkarak \%56 artacağ tahmin edilmektedir. Yine aynı rapora göre küresel çapta 80 yaş ve üzerindeki “en yaşlı” nüfus sayısının diğer yaşlı kişilerin sayısından daha hızlı büyüdüğü belirtilmektedir. 80 yaş üzeri en yaşlı nüfus 2015 yılında \%14 iken 2050 yılında bu oranın \%20'ye çıkması beklenmektedir. Aşağıda Tablo 2'de nüfusun yaşlanma projeksiyonu gösterilmektedir.

Tablo 2. Dünya Nüfusunun Yaşlanma Projeksiyonu

\begin{tabular}{|l|r|r|r|r|r|r|r|r|r|r|}
\hline & \multicolumn{4}{c|}{$\begin{array}{c}\text { 60 Yaş Üstü Nüfusun } \\
\text { Toplam Nüfusa Oranı }\end{array}$} & \multicolumn{5}{c|}{$\begin{array}{c}\text { 80 Yaş Üstü Nüfusun } \\
\text { Toplam Nüfusa Oranı }\end{array}$} \\
\hline & $\mathbf{2 0 0 0}$ & $\mathbf{2 0 0 5}$ & $\mathbf{2 0 1 0}$ & $\mathbf{2 0 3 0}$ & $\mathbf{2 0 5 0}$ & $\mathbf{2 0 0 0}$ & $\mathbf{2 0 0 5}$ & $\mathbf{2 0 1 0}$ & $\mathbf{2 0 3 0}$ & $\mathbf{2 0 5 0}$ \\
\hline Dünya & 9,9 & 10,2 & 11 & 16,5 & 21,9 & 1,1 & 1,3 & 1,5 & 2,3 & 4,3 \\
\hline $\begin{array}{l}\text { Gelişmiş } \\
\text { Ülkeler }\end{array}$ & 19,5 & 20,1 & 21,8 & 28,8 & 32,6 & 3,1 & 3,7 & 4,3 & 6,4 & 9,5 \\
\hline $\begin{array}{l}\text { Az } \\
\text { Gelişmiş } \\
\text { Ülkeler }\end{array}$ & 7,5 & 8 & 8,6 & 14,2 & 20,2 & 0,7 & 0,8 & 0,9 & 1,6 & 3,5 \\
\hline
\end{tabular}

* ILO (2011), World Social Security Report.

Tablo 2'ye göre; dünya genelinde gelişmekte olan ülkelerdeki yaşlı ve en yaşlı nüfus sayısının diğer ülkelere göre daha çok artış göstermesi beklenmektedir. En az artış az gelişmiş ülkelerde görülürken çok gelişmiş ülkelerde ortalama seviyede yaşlı ve en yaşlı nüfusun sayıca artışı öngörülmektedir. Yaşlı nüfusun artması tüm dünyada yaşlı nüfusun işgücüne katılımının artışını da beraberinde getirmektedir. Aşağıda Tablo 3'te 1990, 2000 ve 2015 yıllarında yaşlı kadın ve erkeklerin işgücüne katılım oranları bölgeler bazında verilmiştir.

Tablo 3. Yaşlı Kadın ve Erkeklerin Bölgelere Göre Işgücüne Katılım Oranları

\begin{tabular}{|c|c|c|c|c|c|c|}
\hline & \multicolumn{3}{|c|}{ Erkek } & \multicolumn{3}{|c|}{ Kadın } \\
\hline & 1990 & 2000 & 2015 & 1990 & 2000 & 2015 \\
\hline Avrupa & 9 & 9 & 10 & 4 & 4 & 6 \\
\hline Okyanusya & 12 & 13 & 21 & 5 & 6 & 12 \\
\hline Asya & 41 & 39 & 35 & 12 & 16 & 16 \\
\hline $\begin{array}{l}\text { Kuzey } \\
\text { Amerika }\end{array}$ & 16 & 17 & 23 & 8 & 9 & 14 \\
\hline $\begin{array}{l}\text { Latin } \\
\text { Amerika } \\
\text { ve } \\
\text { Karayipler }\end{array}$ & 41 & 40 & 38 & 10 & 14 & 17 \\
\hline Afrika & 57 & 54 & 52 & 31 & 31 & 33 \\
\hline Dünya & 32 & 31 & 30 & 10 & 13 & 15 \\
\hline
\end{tabular}

*United Nations (2015), World Population Prospects: The 2015 Revision 
Tablo 3'te görüldüğü gibi yaşlı erkeklerin işgücüne katılımı Asya, Latin Amerika, Karayipler ve Afrika'da azalmaktadır. Yaşlı kadınlarınsa tüm bölgelerde işgücüne katılımının arttığı görülmektedir. Dünya genelinde yaşlı kadınların işgücüne katılım oranı \%10 seviyesinden \%15'e yükselirken; erkekler de \%32 seviyesinden \%30'a gerilediği görülmektedir. Ancak erkeklerde de bu oranın 'merkez' bölgelerde arttığı görülüyor. Bu hususun ne anlama geldiği, aşağıda eğitim-geliştirme bahsinde ele alınacaktır.

Nüfusun yaşlanması dünya genelinde emeklilik sistemini de etkilemektedir. Brüt emeklilik yenileme oranı emeklilik sisteminin ne kadar etkin bir şekilde uygulandığının göstergesidir ve emeklilerin gelir kaynağını sağlamaktadır. Aşağıda Tablo 4’te seçili ülkelerde kamu emeklilik harcamalarının GSYİH (Gayrisafi Yurtiçi Hasıla) içindeki yüzdelik payları verilmiştir.

Tablo 4. Emeklilik Harcamaları (GSYiH \%)

\begin{tabular}{|l|r|r|r|}
\hline & $\mathbf{2 0 1 5}$ & $\mathbf{2 0 3 0}$ & $\mathbf{2 0 5 0}$ \\
\hline Afrika & 12,9 & 11,7 & 8,9 \\
\hline Asya & 8 & 5,1 & 3,2 \\
\hline Latin Amerika ve & & & \\
Karayipler & 7,6 & 5 & 2,9 \\
\hline Okyanusya & 4,8 & 3,5 & 3 \\
\hline Kuzey Amerika & 4 & 2,6 & 2,4 \\
\hline Avrupa & 3,5 & 2,4 & 1,9 \\
\hline Dünya & 7 & 4,9 & 3,5 \\
\hline
\end{tabular}

${ }^{\star}$ United Nations (2015), World Population Prospects: The 2015 Revision

Tablo 4'te görüldüğü gibi incelenen tüm ülkelerde 2015 yılına göre 2030 ve 2050 yıllarında emeklilik harcamalarının düşmesi beklenmektedir. Yaşlı ve en yaşlı nüfusun sayısı artarken emeklilik ödeneklerinin azalması 65 yaş üstü kişilerin emekliliktense çalışma hayatı içinde kalacaklarının bir işareti olarak okunabilir.

Türkiye yaşlı nüfusun toplam nüfusa oranının yükseklik sıralamasında 167 ülke arasında 66 . sırada yer almaktadır. TÜİK (2017) raporuna göre; Türkiye'de yaşlı nüfusun toplam nüfus içindeki oranı 2012 yılında \%7,5 iken, 2016 yılında \%8,3’e yükselmiştir. Aşağıda Tablo 5, 2012 ve 2016 yıllarında yaşlı nüfus oranını göstermektedir. 
Tablo 5. Yaş Gruplarının Yaşıı Nüfus İçindeki Oranları (\%)

\begin{tabular}{|l|r|r|}
\hline & $\mathbf{2 0 1 2}$ & $\mathbf{2 0 1 6}$ \\
\hline 65-74 Yaş & 60,3 & 61,5 \\
\hline 75-84 Yaş & 32,5 & 30,2 \\
\hline 85+ Yaş & 7,1 & 8,2 \\
\hline
\end{tabular}

*TÜIK 2017 İstatistiklerle Yaşlılar Raporu

Tablo 5’te görüldügü gibi yaşlı nüfusun \%60,3'ü 2012 yılında 65-74 yaş grubunda, \%32,5'i 7584 yaş grubunda ve \%7,1'i 85 ve daha fazla yaş grubunda iken; 2016 yılında \%61,5'i 65-74 yaş grubunda, \%30,2'si 75-84 yaş grubunda ve \%8,2'si 85 ve daha fazla yaş grubunda yer almaktadır. Kısaca 65-74 yaş aralığı ile 85 ve üstü yaş gurubunda artış olduğu görülmektedir. Yaşlı nüfusun toplam nüfusa oranı 1935 yılından 2075 yılına kadar tahmini olarak aşağıda Tablo 6'da verilmiştir.

Tablo 6'da görüldüğü gibi yaşlı nüfusun genel nüfus içindeki payının artacağı öngörülmektedir. 1935 yılında \%3,9 olan oranın 2012 yılında \%7,5 olduğu görülmüş ve bu oranın 2050 yılında \%20,8; 2075 yılında ise \%27,7 olması beklenmektedir. Kadın yaşlı sayısının erkeklere oranla daha çok olacağı da yine tahminler arasında yer almaktadır. 1935 yılında \%3,5 olan erkek yaşlıların oranının 2075 yılında \%25,4 olacağı öngörülürken; 1935 yılında \%4,2 olan kadın yaşlıların genel nüfusa oranının 2075 yılında \%29,9 olacağı tahmin edilmektedir. Genel olarak yaşam sürelerinde artış görülmektedir. Aşağıda Tablo 7, yaş ve cinsiyete göre beklenen yaşam sürelerini göstermektedir.

Tablo 7'de görüldüğü gibi 2015 yılı hayat tabloları sonuçlarına göre beklenen yaşam süresi Türkiye geneli için 78 yıl; ortalama olarak erkekler için 75,3 yıl ve kadınlar için de 80,7 yıl olarak öngörülmektedir. Ülkemizde 65 yaşında olan bir kişinin kalan yaşam süresi ise ortalama 17,8 yıl olarak belirtilmektedir. Erkekler için bu sürenin 16,1 yıl, kadınlar için 19,4 yıl olduğu gözlenmiştir. Genel olarak 65 yaşına ulaşan kadınların erkeklerden ortalama 3,3 yıl daha fazla yaşayacağı tahmin edilmektedir. Aslında bu durum ortanca yaşın da değişimine yol açmaktadır. Aşağıda Tablo 8, cinsiyete göre ortanca yaştaki değişimi göstermektedir. 
Tablo 6. Yaşlı Nüfusun Toplam Nüfus İçindeki Oranı 1935-2075

\begin{tabular}{|c|c|c|c|c|c|c|c|c|c|c|c|}
\hline & & Toplam & Nüfus & & Yaşlı N & üfus & & $\begin{array}{l}\text { Yaşli Ni } \\
\text { oplam } 1 \\
\text { Ora }\end{array}$ & $\begin{array}{l}\text { ffusun } \\
\text { Nüfusa } \\
\text { nı }\end{array}$ & Genel & \\
\hline & Toplam & Erkek & Kadın & Toplam & Erkek & Kadın & Toplam & Erkek & Kadın & Oranı & Oranı \\
\hline 1935 & 16158 & 7937 & 8221 & 628 & 279 & 349 & 3,9 & 3,5 & 4,2 & 96,5 & 79,9 \\
\hline 1940 & 17821 & 8899 & 8922 & 630 & 271 & 358 & 3,5 & 3 & 4 & 99,7 & 75,7 \\
\hline 1945 & 18790 & 9447 & 9344 & 627 & 257 & 370 & 3,3 & 2,7 & 4 & 101,1 & 69,4 \\
\hline 1950 & 20947 & 10527 & 10420 & 691 & 273 & 418 & 3,3 & 2,6 & 4 & 101 & 65,3 \\
\hline 1955 & 24065 & 12333 & 11831 & 822 & 321 & 502 & 3,4 & 2,6 & 4,2 & 103,4 & 63,9 \\
\hline 1960 & 27755 & 14164 & 13591 & 979 & 388 & 591 & 3,5 & 2,7 & 4,3 & 104,2 & 65,7 \\
\hline 1965 & 31391 & 15997 & 15394 & 1243 & 530 & 713 & 4 & 3,3 & 4,6 & 103,9 & 74,4 \\
\hline 1970 & 35605 & 18007 & 17598 & 1566 & 708 & 858 & 4,4 & 3,9 & 4,9 & 102,3 & 82,5 \\
\hline 1975 & 40348 & 20745 & 19603 & 1853 & 851 & 1003 & 4,6 & 4,1 & 5,1 & 105,8 & 84,8 \\
\hline 1980 & 44737 & 22695 & 22042 & 2113 & 955 & 1158 & 4,7 & 4,2 & 5,3 & 103 & 82,5 \\
\hline 1985 & 50664 & 25672 & 24992 & 2126 & 955 & 1171 & 4,2 & 3,7 & 4,7 & 102,7 & 81,6 \\
\hline 1990 & 56473 & 28607 & 27866 & 2417 & 1091 & 1326 & 4,3 & 3,8 & 4,8 & 102,7 & 82,3 \\
\hline 2000 & 64730 & 32399 & 32331 & 3859 & 1750 & 2109 & 6 & 5,4 & 6,5 & 100,2 & 82,9 \\
\hline 2005 & 68861 & 34491 & 34370 & 4647 & 2011 & 2636 & 6,7 & 5,8 & 7,7 & 100,4 & 76,3 \\
\hline 2007 & 70586 & 35362 & 35224 & 4865 & 2096 & 2769 & 6,9 & 5,9 & 7,9 & 100,4 & 75,7 \\
\hline 2008 & 71517 & 35901 & 35616 & 4893 & 2139 & 2754 & 6,8 & 6 & 7,7 & 100,8 & 77,7 \\
\hline 2009 & 72561 & 36462 & 36099 & 5083 & 2223 & 2861 & 7 & 6,1 & 7,9 & 101 & 77,7 \\
\hline 2010 & 73723 & 37043 & 36680 & 5328 & 2331 & 2997 & 7,2 & 6,3 & 8,2 & 101 & 77,8 \\
\hline 2011 & 74724 & 37533 & 37191 & 5491 & 2398 & 3093 & 7,3 & 6,4 & 8,3 & 100,9 & 77,5 \\
\hline 2012 & 75627 & 37956 & 37671 & 5682 & 2474 & 3208 & 7,5 & 6,5 & 8,5 & 100,8 & 77,1 \\
\hline 2013 & 76668 & 38473 & 38195 & 5892 & 2561 & 3331 & 7,7 & 6,7 & 8,7 & 100,7 & 76,9 \\
\hline 2014 & 77696 & 38984 & 38712 & 6193 & 2699 & 3949 & 8 & 6,9 & 9 & 100,7 & 77,3 \\
\hline 2023 & 84247 & 42137 & 42110 & 8624 & 3831 & 4793 & 70,2 & 9,1 & 11,4 & 100,1 & 79,9 \\
\hline 2035 & 90680 & 45260 & 45421 & 13158 & 5936 & 7222 & 14,5 & 13,1 & 15,9 & 99,6 & 82,2 \\
\hline 2040 & 92258 & 45986 & 46272 & 15243 & 6871 & 8372 & 16,5 & 14,9 & 18,1 & 99,4 & 82,1 \\
\hline 2045 & 93175 & 46377 & 46798 & 17476 & 7893 & 9583 & 18,8 & 17 & 20,5 & 99,1 & 82,4 \\
\hline 2050 & 93476 & 46462 & 47013 & 19485 & 8814 & 10670 & 20,8 & 19 & 22,7 & 98,8 & 82,6 \\
\hline 2055 & 93278 & 46304 & 46974 & 20982 & 9487 & 11494 & 22,5 & 20,5 & 24,5 & 98,6 & 82,5 \\
\hline 2060 & 92717 & 45975 & 46742 & 22248 & 10040 & 12209 & 24 & 21,8 & 26,1 & 98,4 & 82,2 \\
\hline 2065 & 91800 & 45481 & 46319 & 23525 & 10625 & 12901 & 25,6 & 23,4 & 27,9 & 98,2 & 82,4 \\
\hline
\end{tabular}

${ }^{*}$ TÜIK, Nüfus Projeksiyonu 1935-2075 
Tablo 7. Yaş ve Cinsiyete Göre Beklenen Yaşam Süresi

\begin{tabular}{|c|c|c|c|}
\hline Yaş & Toplam & Erkek & Kadın \\
\hline $\mathbf{0}$ & 78 & 75,3 & 80,7 \\
\hline $\mathbf{1 5}$ & 64,2 & 61,6 & 66,9 \\
\hline $\mathbf{3 0}$ & 49,7 & 47,1 & 52,1 \\
\hline $\mathbf{5 0}$ & 30,6 & 28,3 & 32,8 \\
\hline $\mathbf{6 5}$ & 17,8 & 16,1 & 19,4 \\
\hline
\end{tabular}

${ }^{*}$ TÜIKK Hayat Tabloları.

Tablo 8. Cinsiyete Göre Ortanca Yaş 1935-2075

\begin{tabular}{|c|c|c|c|c|c|c|}
\hline & \multicolumn{3}{|c|}{ Toplam Nüfus } & \multicolumn{3}{|c|}{ Yaşlı Nüfus } \\
\hline & Toplam & Erkek & Kadın & Toplam & Erkek & Kadın \\
\hline 1935 & 21,2 & 19,1 & 23,4 & 72,5 & 72,2 & 72,8 \\
\hline 1940 & 19,6 & 17,7 & 22,4 & 72,4 & 72,2 & 72,5 \\
\hline 1945 & 20 & 18,8 & 21,7 & 72,1 & 71,9 & 72,3 \\
\hline 1950 & 20,1 & 19,2 & 21,3 & 71,9 & 71,6 & 72 \\
\hline 1955 & 20,4 & 19,6 & 21,3 & 72,1 & 71,7 & 72,3 \\
\hline 1960 & 20,3 & 19,5 & 21,1 & 71,8 & 71,2 & 72,1 \\
\hline 1965 & 19,3 & 18,7 & 20 & 71,3 & 70,3 & 71,9 \\
\hline 1970 & 19 & 18,6 & 19,4 & 71,5 & 70,7 & 72,1 \\
\hline 1975 & 19,5 & 19,2 & 19,8 & 72,1 & 71,9 & 72,3 \\
\hline 1980 & 19,9 & 19,5 & 20,3 & 71,6 & 71,2 & 72 \\
\hline 1985 & 20,9 & 20,6 & 21,2 & 72,9 & 72,7 & 73,1 \\
\hline 1990 & 22,2 & 21,9 & 22,6 & 72 & 71,5 & 72,3 \\
\hline 2000 & 24,8 & 24,4 & 25,3 & 71,2 & 70,8 & 71,6 \\
\hline 2007 & 28,3 & 27,7 & 28,8 & 72,9 & 72,3 & 73,4 \\
\hline 2008 & 28,5 & 27,9 & 29 & 72,9 & 72,5 & 73,3 \\
\hline 2009 & 28,8 & 28,2 & 29,3 & 73,1 & 72,6 & 73,5 \\
\hline 2010 & 29,2 & 28,7 & 29,8 & 73 & 72,5 & 73,4 \\
\hline 2011 & 29,7 & 29,1 & 30,3 & 73 & 72,5 & 73,5 \\
\hline 2012 & 30,1 & 29,5 & 30,6 & 73 & 72,5 & 73,5 \\
\hline 2013 & 30,4 & 29,8 & 31 & 73 & 72,4 & 73,4 \\
\hline 2014 & 30,7 & 30,1 & 31,3 & 72,8 & 72,3 & 73,3 \\
\hline 2023 & 34 & 29,8 & 31 & 72,4 & 71,7 & 72,9 \\
\hline 2050 & 42,9 & 41,8 & 44 & 74 & 73,4 & 74,6 \\
\hline 2075 & 47,4 & 46 & 48,7 & 76,3 & 75,3 & 77,1 \\
\hline
\end{tabular}

*TÜİK 2017 Nüfus Projeksiyonu 
Tablo 8'de görüldüğü gibi 1935 yılında 21, 1940'da 19, 2000 de 24, 2014'te 30 olan ortanca yaşın 2023 yılında 34, 2050'de 42 ve 2075 yılında ise 47 olacağı öngörülmektedir. Bunun nedeni yaşlı nüfus sayısındaki artış olarak gösterilmektedir.

Günümüzde dünyada insanlar daha uzun yaşamakta, doğum oranları azalmakta ve dolayısıyla yaşlı nüfus sayısal ve oransal olarak artmaktadır. Nüfusun yaşlanması, küresel ölçekte 21. yüzyılın en önemli demografik ve sosyal olgularından biri olarak kabul edilmektedir. Nüfusun yaşlanması, sağlıktan sosyal güvenliğe; çevre ile ilgili konulardan eğitime; iş olanaklarından, sosyokültürel faaliyetlere; aile hayatından ekonomiye kadar toplumda çeşitli sonuçlar doğurmaktadır. Yaşlanma, sosyal açıdan toplumdaki aile yapısını, yaşam düzenini, tavır ve davranış kalıplarını, kuşaklar arası ilişkileri ve toplumsal yaşamın diğer alanlarını etkilerken; ekonomik açıdan da yaşlı nüfusun desteklenmesinin topluma olan ekonomik maliyetini artırmakta, işgücünün demografik yapısını değiştirmek suretiyle de istihdamı ve işgücü piyasalarını önemli ölçüde etkilemektedir (Samorodov,1999, s.4). Tüm bu bilgiler ışığında sonuç olarak dünya nüfusu yaşlandığı için işgücü de yaşlanıyor diye ifade edebiliriz. İşünün yaşlanması ise bu kesimin eğitim-geliştirme faaliyetleriyle olan ilişkilerinin daha da artması anlamina gelmektedir.

\section{Cari Koşullar ve Söylem Üretimi: Küresel Yaşlanmanın Eğitim ve Geliştirme Alanı Açısından Önemi Nedir?}

Günümüzün en belirgin alametifarikalarından birisi değişimin hızıyla ilgilidir, bunun ise çok sayıda sonucu bulunmaktadır. Değişimin hızı, dünyaya dair sahip olduğumuz bilgilerin sürekli bir şekilde tedavülden çıkması ve değişmesi anlamına gelmektedir. Bauman (2010, s.7)'ın ifadesiyle, “..dün doğru dediğini bugün inkar eden, aynı zamanda bu gece doğru addettiklerimizin yarın sabah çürütülemeyeceğine dair pek de teminat vermeyen bu dünyayı anlamak için” sürdürülen çaba gerçekten de sıkı bir mücadele anlamına gelmektedir. Bir söylemin üretilmesinin ya da söylemin değişmesinin nasıl da 'zamanın ruhu' ile ilgili olduğunu Bauman (2010)'ın aynı çalışmasının giriş bölümünde aktardığı Londra Zooloji Topluluğu üyesi bir grup araştırmacının yaşadığı zihinsel maceraya bakarak kavramak mümkündür. Söz konusu bu topluluğun üyesi olan araştırmacılar ileri teknoloji ile donatılmış bir şekilde yaban arılarının hareketlerini izleyip kaydettiler. Kayıtların incelenmesiyle ulaştıkları sonuç, sosyal böceklerin tabiatlarına dair uzun süredir kabul edilen kalıpları yerle bir etmiştir.

Bu hikâyenin buradaki çalışmamızla ilgili olan kısmı zamanın ruhuna uygun düşen bir söylemin pek de sorgulanmadan varlığını sürdürdüğ̈ hususudur. Bauman (2010, s.9)'ın ifade ettiği gibi 'sosyal böcekler' kavramının icat edildiği ve yaygınlaştı̆̆ günlerden bu yana 'bilgi sahibi zoologlar ile halk neredeyse hiç sorgulanmayan katı bir inancı paylaştılar.' Bu inanç, kısaca söz konusu böceklerin sosyalliğinin, içinde bulundukları toplulukla sınırlı olduğuna yönelikti. Ancak önemli olan husus bu inancın ya da aksiyomun da tüm aksiyomlar gibi daha önce hiç sorgulanmamış ve sınanmamış olmasıydı. Çünkü bu böceklerin sadece kendi toplulukları' içinde kalacakları fikri akla ya da dönemin sosyal kabullerine yatkındı. Ancak tartışma kabul etmez kabuller de zamanla değişir. 'Bu değişim, insanlık durumundaki ve onun 
getirdiği külfetlerdeki değişimlerle birlikte gerçekleşir.' Bilimsel gündemlerin insan pratiklerinin türevleri olduğunu öne süren Bauman (2010, s.10), genel geçer bilginin değişmemesini, bu yöndeki bir gereksinimin doğmamasına bağlamaktadır:

"Bu sebeple, ĕger yaygin genelgeçer bilgiyi sınamak için hiç çaba harcanmamışsa bunun, araştırma araçlarının yetersizliğinden çok, bu tür yaygın bilginin güvenilirliğinin tartışılır hale gelmemesiyle bu sınamanın gerektiğine dair bir kuşkunun doğmamış olmasından kaynaklandı̆̆ı kanısına varmaya hakkımız var[dır]."

Kısacası, araştırma ekibi, 'işçi yaban arılarının’ yüzde 56’sına denk gelen önemli bir oranının yaşamları boyunca yuva değiştirdikleri sonucuna varmışlardır. Bauman tüm bu hikayeyi, aslında bilimsel bilgilerin bile dönemin bir ürünü olan insan aktörlerin zihinsel yansımalarıyla ilgili olduğunu göstermek amacıyla anlatmaktadır.

'Sosyal böcekler' ile ilgili yaygın kabullerin değişim hikayesinin bu çalışmayla ilgisi nedir? Bu soruya cevap vermeden önce iktisat tarihinden bir örnek daha sunmak yerinde olacaktır. Bilindiği gibi kapitalizmin gelişimi ile ilgili moral kaynaklardan bahsedildiğinde ilk akla gelen isimlerin başında Max Weber'in meşhur 'protestan etik tezi' gelir. Weber (2011), bu yaklaşımında kapitalizmin maddi olmayan kaynaklarına son derece önemli roller atfeder (ayrıca benzer bir çalışma için bkz. Sombart, 2016). Buradaki çalışmamız bağlamında bu tezin içeriğini açmaktan ziyade bazı fikirlerin nasıl da belirleyici hale geldiklerine işaret etmek önemlidir. Bilindiği gibi ortaçağ Avrupası, Katolizmin katı yorumlarıyla şekillenen bir dünya idi. Kapitalizmin gelişimini anlatan tüm metinler mutlaka 'Reformasyon' hareketine işaret ederler. Buna göre 'Reformasyon' ticaretin ya da iktisadi gelişimin önündeki engelleri geçişken hale getiren bir harekettir. Bu noktayı en açık şekilde ifade eden isimlerden birisi Fransız tarihçi Lucien Febvre'dir. Fevbre, Reform hareketinin, bu hareketin temel aktörlerinin kendi entelektüel serüvenlerinin bir neticesi olarak ortaya çıtı̆̆ını ve temel amaçlarının ise burjuva sınıfının çıkarlarını geliştirmekle bir ilgisinin olmadığını belirtmektedir. Ancak sonuç, tam da bu olmuştur, burjuvazinin çıkarlarına hizmet eden bir moral dayanak. Dolayısıyla bir zamanın egemen Katolik yorumu, ya tamamen değişmiş ya da büyük ölçüde esnetilmiş oldu.

"XV. yüzyıl insanları XVI. yüzyıl burjuvaları büyük ıslahatçıların kalp ve vicdanlarından çıktığı haliyle aldıkları bu Reformasyonu, biraz günah işleyerek dönüştürmüşler, değiştirmişler ve onu tamamen kendilerine ait bir Reformasyon haline getirmişlerdir. Reformasyon daha sonra onlardan uzaklaşarak, kendine ait, özerk, bağımsız bir hayat sürdürmeye başlamış ve bu sefer, o insanların zihniyeti üzerinde etki etmeye başlamıştır" (Febvre, 1995, s.102).

Yukarıdaki soruya dönmeden önce son olarak gündelik hayattan da bir örnek verelim. Harari (2017)'nin çalışmasında, işaret ettiği toplumsal cinsiyet meselesi bu noktada anlamlıdır. Harari, çalışmasında eski Atina ile günümüz Atinası'nın kadınlara bakışındaki değişimi aktarmaktadır. Buna göre eski Atina'da kadınlar, oy veremez, hâkim olamaz, hükümette görev alamaz, kiminle evleneceğine kendisi karar veremez, genelde okuma yazma bilmez ve yasal olarak da kocaya veya babaya aitken modern Atina'da tüm bu engeller değişmiş durumdadır. Yani kadınlarla ilgili başka bir 'gerçeklik' hâkim durumdadır. Bu konunun daha güncel bir örneği Suudi 
Arabistan'dır. Bilindiği gibi son zamanlarda Suudi Arabistan'da özellikle de kadınlar açısından toplumsal hayatı doğrudan ilgilendiren açılım ile ilgili gelişmeler yaşanmaktadır. Bu 'açılımın' amaçları medyada 'analistler' tarafından çokça yapıldı veya yapılmaktadır (örneğin bkz. Tekfidan Gümüş, 2017) ancak yine konunun bu çalışma bağlamındaki önemi bir dönem 'hakikat' veya 'gerçeklik' olarak gösterilen kabullerin 'zamanın ruhuna' veya 'günün gereksinimlerine’ göre terkedilmesi ve yerlerine yeni kabullerin veya gerçekliklerin konmaya çalışılmasıdır.

Şimdi gelelim yukarıda sorduğumuz soruya: sosyal böcekler, iktisat tarihi ve gündelik hayatta toplumsal cinsiyetin konumlandırılması ile ilgili bu örneklerin eğitim ve geliştirme ile ilgili bir tartışmada ne işi var? Bu üç örnek de şunu göstermek için kullanıldı: Yaygın kabuller zamanın ihtiyaçlarına göre değişebilir ve yerlerini yeni kabullere, söylemlere ve gerçekliklere bırakabilirler. Evet, artık sosyal böceklerin tüm yaşamlarını tamamen izole, kapalı topluluklar içinde geçirmediklerini, örneğin dinin 'faiz' yasağının artık farklı yorumlarla esnetildiğini ve kadının baba veya eşe ait olmayan özgür birer insan olduğunu biliyoruz.

İçinde bulunduğumuz değişim dalgasının getirdiği gereksinimlerden birisi eğitimin önemi ile ilgilidir. Bilindiği gibi eğitim ve geliştirme alanı insan kaynakları yönetiminin en hızlı gelişen alanlarından birisidir. Bu alanda yapılan harcamalar ve her yıl bu harcamaların artması örgütlerin öğrenmenin önemini kavramış olduklarının bir işareti olarak görülebilir. Bu alanda yayınlanan bir rapora göre (ATD, 2013), ABD'de 2012 yılında örgütlerin eğitim faaliyetleri için yapmış oldukları harcamalar, 165 milyar dolardır.

Bu noktada firmaları her geçen gün eğitime daha da fazla yönlendiren yapısal unsurlar neler? Bunların başında yukarıda bahsedilen değişim dalgası ile küresel yaşlanma meselesi gelmektedir. Söz konusu değişim dalgasının en belirgin göstergelerinden birisi imalata dayalı iktisadi yapının hizmete dayalı bir yapıya dönüşmesidir. Bunun anlamı, geleneksel imalat istihdam eğrisinin ya yatay ya da aşağıya doğru bir seyir takip ediyor olmasıdır. Başka bir ifadeyle, yeni işler ve yeni istihdam kalıpları ortaya çıkmaktadır. Bu değişimi tetikleyen en önemli göstergelerden birisi de teknolojidir. Teknoloji hem çok hızlı bir değişimin taşıyıcısı hem de esnekliği mümkün kılan temel bir değişken olarak karşımıza çıkmaktadır. Dolayısıyla örgütler dünyasına bakıldığında, örgütlerin karşı karşıya bulundukları en önemli meselelerin başında bu hızlı değişime nasıl ayak uyduracakları meselesi gelmektedir. Bunun anlamı, örgütlerin kendilerini sürekli bir şekilde güncellemek durumunda olduklarıdır. İnsan kaynakları yönetiminin eğitim ve geliştirme işlevi ise bu güncellemeyi mümkün kılan temel aracı konumundadır.

Ama, ya yaşlanma meselesi? Yaşlanma meselesi, yukarıda da ayrıntılı bir şekilde işaret edildiği gibi gelişmiş ülkelerin başlıca gündem konularından birisidir (örneğin bkz. The Guardian, 2013; The Irish Times, 2017). Yaşlanma sorunuyla karşı karşıya olan ülkelerin temel kaygılarından birisi sosyal güvenlik sistemleriyle ilgilidir. Yaşlanma, ortalama yaşam süresinin uzaması anlamına gelmektedir ve bu duruma 'bir muhasebe' gözlüğü ile bakıldığında ise tablo, sosyal güvenlik sistemleri açısından bir yük olarak yorumlanmaktadır. Çünkü uzun süren emeklilik dönemleri, sistemin aktif-pasif dengesini bozucu bir unsur olarak ele alınmaktadır. 
Dolayısıyla ya emekli olma yaşı uzatılmakta ya da emekliliğin sağlamış olduğu güvenceler cezbedici olmaktan çıkartılmaktadır. Dolayısıyla insanların aktif çalışma süreleri uzatılmış olmaktadır. Finlandiya Sağlık ve Sosyal İşler Bakanlı̆̆ı'na bağlı olan Emeklilik Merkezi'nin yayınlamış olduğu bir projeksiyona göre 2050 yılına kadar İzlanda, Danimarka ve Hollanda'da emeklilik yaşının 70'in üstene çıkması beklenmektedir (ayrıca diğer ülkeler için de bkz. FCP, 2018). Söz konusu projeksiyonda bütün üye ülkelerin emeklilik yaşlarının arttığı görülmektedir (ayrıca bkz. Christie, 2017). Elbette ki Türkiye'de de benzer bir eğilim bulunmakta ve şu anda 50 civarında olan emeklilik yaşının, daha önce başlatılan sosyal güvenlik reformuyla 58-60'a 2037'den sonra ise 65'e çıkartılması planlanmaktadır (Haber Türk, 2017). Kısacası, insanların beklenen yaşam süreleri arttıkça onları emek piyasasında aktif bir biçimde tutmaya yönelik düzenlemeler de bu artışa eşlik etmektedir.

Öyleyse bu tabloya uygun bir söylemin tam zamanıdır denilebilir. Ortalama yaşam sürelerinin daha kısa olduğu bir dünyada, belli bir yaşın üstündekileri çalışma hayatında daha fazla tutmanın pek bir anlamı yoktu, dolayısıyla 'dinozor yaşlı' tabiri bu dünyanın ruhuna uygun bir ifadeydi. Gerçekten de yakın zamana kadar yaşlılarla ilgili en yaygın klişeler, onların 'dinozorluklarına', 'katılıklarına' ve 'uyum sağlama kabiliyetlerinin zayıflıklarına' yönelikti. Belli bir yaşın üstündeki çalışanların bu şekilde ele alınması, eğitim ve geliştirme faaliyetlerinin de onlar açısından bir ümit vadetmediği sonucunu çıkartıyordu. Ancak yaşlıların yeni durumlara uyamayacak kadar katı olduklarına yönelik bu yaygın-popüler söylemin, aslında gerçekleri yansıtmadığına yönelik yeni ve güçlenmekte olan bir söylem ortaya çıkmaktadır. Bu yeni söylem, aynı zamanda eğitim ve geliştirme faaliyetlerinin her geçen gün daha da fazla önemsenmesine katkıda bulunmaktadır.

$\mathrm{Bu}$ alandaki yazına bakıldığında yaşlılarla ilgili yukarıda bahsedilen klişelerin genelde birer 'efsane' olarak ele alındığı ve dolayısıyla bu 'efsanelerin' gerçeği yansıtmadığına yönelik iddiaları görmek mümkündür. Withnall (2004), yaşlıların yeni şeyler öğrenmeleri ile ilgili yaygın efsaneleri şu şekilde sıralamıştır: Yaşlıların söylemeye değer bir şeylerinin olmadığı, yaşlıların kolayca unutmaya meyilli oldukları ve yeni bir şeyleri öğrenmede son derece yavaş oldukları, yaşlı insanların geçmişe saplandıkları, orada yaşadıkları ve değişimi sevmedikleri, yaşlı insanların öğrenmeye ilgi duymadıklarına yönelik efsaneler. Withnall bu ve başka çalışmalarında (örneğin bkz. 2010) tüm bu efsaneleri sorgulamakta ve belirli bir yaşın üstündeki insanların da öğrenmeye ne denli açık olduklarını göstermeye çalışmaktadır. Avustralya'daki Queensland Eyalet Yönetimi'nin yayınlamış olduğu bir raporda bu efsanelerin listesi daha da uzundur (QG, 2012, s.30-31, bir başka efsaneler listesi için bkz. Farrell, 2016). Bu raporda bizim buradaki tartışma konumuzla ilgili olan efsane, yaşlıların öğrenemedikleri ya da değişemediklerine yönelik olan efsanedir. Rapor bu efsanenin doğru olmadığını bazı veriler aktararak çürütmeye çalışmaktadır. Örneğin, 2002 yılında 45-64 yaş arasındakilerin yüzde 6.9’u mesleki eğitim sistemine katılmıştır, bu oran, 1994 yılında ise 3.4 idi. Bruyere ve arkadaşları (2012) ise yaşlılarla ilgili yaygın efsaneleri değişimden korkan, teknolojiye uyumda yetersiz olan, yavaş öğrenen, yaratıcılıktan yoksun olan, düşük performans gösteren, düşük motivasyonlu, düşük düzeyde esnek olan bir grup şeklinde sıraladıktan sonra 'gerçekleri' ise şu şekilde sunmaktadırlar: düşük devir oranları, kaliteye bağlılık, devamsızlıkta bulunmamak ve 
dakiklik, düşük iş kazası oranları, yüksek motivasyon ve örgütsel bağlılık, güçlü bir iş etiği ve deneyim, sadakat ve güvenilirlik, farklı iş planlarına uygunluk, düşünce ve deneyimlerdeki farklilik.

Burada dikkat çeken husus, yukarıda 'klişe' olarak vurgulanan algının yazında sıklıkla 'efsaneler' olarak ortaya konmasıdır. Bunun anlamı, bu çalışmada ortaya konmaya çalışılan yeni bir söylemin üretilmesiyle ilgilidir. Cari koşullar yeni ihtiyaçlar doğurmakta bu ihtiyaçlar ise yeni söylemler üretmektedir. Eğitim ve geliştirme alanı açısından bakıldığında, yaşlılarla ilgili olan eski söylemin, yerini, yaşlıların olumlu özelliklerini ön plana çıkartan yeni bir söyleme birakmakta olduğunu söylemek mümkündür.

\section{Sonuç Yerine}

Eurofound (2017, s.6)'un 2015 yılında farklı yaşlardaki çalışanların yaşam koşulları ile ilgili yapmış olduğu bir taramanın sonuç raporu, sürdürülebilir bir çalışma yaşamı için eğitim ve geliştirme faaliyetlerine katılan yaşlı çalışan oranlarının arttırılmasının öncelikli bir politika olması gerektiğine vurgu yapmaktadır. Bir başka çalışma ise yaşlılara yönelik eğitim geliştirme faaliyetlerinin gerçekleştirilmesinin, yaşlıların hem örgüte yönelik memnuniyetlerini hem de onların örgütte tutulmasını sağlamaya katkı yaptığına yönelik bulgular ortaya koymaktadır (Armstrong-Strassen ve D. Ursel, 2009).

Yukarıdaki tartışmalarla birlikte düşünüldüğünde tüm bunlar eğitim ve geliştirme alanı için ne anlama geliyor? Eğitim ve geliştirme alanı mademki çalışanları ve dolayısıyla örgütü hızlı değişim dalgası içinde güncelleyen ve çalışanlar ile kurumları bu dalgaya uyumlu hale getiren bir alandır öyleyse bu alanın yaşlıların çalışma yaşamlarına uyumlarını sağlamaya yönelik bir amacı bulunmalı eğer böyle bir amacı yoksa da bu tür bir amaç mutlaka edinmelidir. Özellikle yetişkin eğitimi (androgoji) ile ilgili tartışmalar, eğitim ve geliştirmenin yetişkinlere yönelik yaklaşımının netleşmesinde ve yukarıda bahsedilen söylemin yerleşmesinde önemli bir yer tutmaktadır. Androgoji ayırımı, yetişkinleri kendilerine has özellikleri ile ele almakta ve onlara yönelik eğitimlerin mutlaka bu farklılıkları dikkate almaları gerektiğini ortaya koymaktadır. Pedagojiden farklı olan bu yaklaşıma, yukarıda bahsedilen yapısal değişimler -imalattan hizmetlere kayan bir ekonomi ve küresel yaşlanma- de eklendiğinde, yaşlilarla ilgili geleneksel kalıpların gerçekleri yansıtmayan 'efsaneler' olarak ele alınmaya başlandığını görüyoruz. Yeni söylem artık yaşlıların örgütler için bir ayak bağı değil birer firsat olduğunu, onların zengin tecrübe repertuvarlarıyla örgüte katkı sağlayacak aktörler olduğunu, yaşlıların değişime kapalı, katı aktörler değil de tecrübeleriyle her tür değişime rahatlıkla uyum sağlama kabiliyetine sahip çalışanlar olduğunu vb. belirtmektedir. Öyleyse insan kaynakları departmanları da buna uygun politikalar geliştirmeli, onlara uygun eğitim programları tasarlamalı ve yaşlıları güncel koşullara uydurmaya çalışmalıdır.

Sonuç olarak, güçlü değişim dalgaları yeni ihtiyaçlar ortaya çıkartmış, bu ihtiyaçlar ise kendisine uygun -ya da kendisi için işlevsel- bir söylem gereksinimi doğurmuş, bu söylem ise yaşlılar ile ilgili eski klişeleri hakikatten uzak efsaneler olarak ele alıp eğitim ve geliştirme alanına yaşlılarla ilgili önemli roller yüklemiştir. 


\section{Kaynakça}

Armstrong-Strassen, M. and Ursel N. D. (2009). Perceived Organizational Support, Career Satisfaction and the Retention of Older Workers. Journal of Occupational and Organizational Psychology, 82, 201-220.

Atd (2013). ASTD Releases 2013 State of the Industry Report. https://www.td.org/insights/1642billion-spent-on-training-and-development-by-us-companies (Erişim: 05.02.2018).

Bauman, Z. (2010). Etiğin Tüketiciler Dünyasında Bir Şansı Var mı?. Funda Çoban ve İnci Kantarcı (Çev.). Ankara: DeKi Yayınları.

Bloland, H.G. (1995). Postmodernism and Higher Education. Journal of Higher Education, 66, pp.521-559.

Bruyere, S.M. and Young J. and M. Maybaum (2012). The Aging Workforce: Challenges and Opportunities for Providers and Employers. http://www.edi.cornell.edu/download/NCRE_2012_Aging_workforce_presentation.pdf (Erişim: 06.02.2018).

Callinicos, A. (2001). Postmodernizme Hayır Marksist Bir Eleştiri. Şebnem Pala (Çev). Ankara: Ayraç Yayınevi.

Christie, S. (2017). Mapped: Retirement Ages Around the World, the Telegraph, http://www.telegraph.co.uk/pensions-retirement/financial-planning/mappedretirement-ages-around-world/ (Erişim: 05.02.2018).

Clarke, A.E. (2005). Sitiuational Analysis: Grounded Theory After the Postmodern Turn. Thousand Oaks, C.A: Sage.

Dpt (2007). Türkiye’de Yaşlıların Durumu ve Yaşlanma Ulusal Eylem Planı (2007). Yayın No: 2741.

Elliot, A. (2017). Çağdaş Sosyal Teoriye Giriş. İbrahim Yıldız ve Aylin Görgün Baran (Çev.). Ankara: Dipnot Yayınları.

Eurofound. (2017). European Working Condition Survey 2015: Working Conditions of Workers Of Different Ages. Luxembourg: Publications Office Of European Union.

Farrell, C. (2016). Disproving Beliefs About the Economy and Ageing. The New York Times. https://www.nytimes.com/2016/05/14/your-money/disproving-beliefs-about-theeconomy-and-aging.html (Erişim: 05.02.2018).

Fcp. (2018). Retirement Ages in Member States. https://www.etk.fi/en/the-pension-system2/the-pension-system/international-comparison/retirement-ages/ (Erişim: 05.02.2018).

Febvre, L. (1995). Uygarlık, Kapitalizm ve Kapitalistler. Mehmet Ali Kılıçbay (Çev.). Ankara: İmge Kitabevi.

Foucault, M. (2017). Hapishanenin Doğuşu. Mehmet Ali Kılıçbay (Çev.). Ankara: İmge Kitabevi. 
Giddens, A. (2016). Modernliğin Sonuçları. Ersin Kuşdi (Çev.). İstanbul: Ayrıntı.

Green, A. (1994). Postmodernism and State Education. Journal of Education Policy, 9(1), $67-$ 83.

Haber Türk (2017). Türkiye'de Ortalama Emeklilik Yaşı 51-52. http://www.haberturk.com/ekonomi/is-yasam/haber/1459482-turkiyenin-ortalamaemeklilik-yasi-51-52 (Erişim: 05.02.2018).

Harari, Y. N. (2017). Hayvanlardan Tanrılara Sapiens. Ertuğrul Genç (Çev.). İstanbul: Kolektif Kitap.

Lytord, J. F. (2013). Postmodern Durum. İsmet Birkan (Çev.). Ankara: BilgeSu.

Mattelart, A. (2012). Bilgi Toplumunun Tarihi. Halime Yücel (Çev.). İstanbul: İletişim.

Merriam, B. S. (2015). Nitel Araştırma: Desen ve Uygulama İçin Bir Rehber. Selahattin Turan (Çev.). İstanbul: Nobel.

Patton, M. Q. (2002). Çhıaliative Research and Evaluation Methods. Thousand Oaks, CA: Sage.

Qg (2012). Ageing: Myth Reality. https://www.qld.gov.au/seniors/documents/retirement/ageing-myth-reality.pdf (Erişim: 05.02.2018).

Samaradov, A. (1999). Aging and Labour Markets for Older Workers. ILO Employment and Training Papers, 33.

Sardon, J.P. (2006). Population. Recent Demographic Trends in the Developed Countries Population, 61, 197-266.

Sarıbay, A.Y. (2001). Postmodernite, Sivil Toplum ve İslam. İstanbul: Alfa.

Slife, B.D.(1993). What's Behind the Research? Discovering Hidden Assumptions in the Behavioral Sciences. Thousand Oaks, C.A: Sage.

Sombart, W. (2016). Yahudiler ve Modern Kapitalizm. Sabri Gürses (Çev.). İstanbul: Küre.

Spicer, M.W. (2005). Public Administration Enquiry and Social Science in the Postmodern Condition: Some İmplications of Value Pluralism, Administrative. Theory \& Praxis, 27(December), 669-688.

Stringer, E.T. (1993). Socially Responsive Educational Research: Linking Theory and Practice. in D.J. Flinders \& G. E. Mills (Eds.). Theory and Concept in Qualitative Research: Perspectives From the Field, 141-162, New York: Teachers College Press.

Şaylan, G. (2006). Postmodernizm. Ankara: İmge Kitabevi.

Tekfidan-Gümüş, N. (2017). Suudilerin 'Ilımlı İslam’ Açılımı. Hürriyet Gazetesi. 27 Ekim 2017. http://www.hurriyet.com.tr/yazarlar/nilgun-tekfidan-gumus/suudilerin-ilimli-islamacilimi-40624027 (Erişim: 05.02.2018). 
The Guardian (2013). Ageing Population Will Have Huge İmpact on Social Services, Lords Told. https://www.theguardian.com/society/2013/feb/24/britain-ageing-populationlords-inquiry(Erişim: 05.02.2018).

The Irısh Times (2017). Ageing Ireland: Living Longer and Cleaner Brings İts Own Problems. https://www.irishtimes.com/news/health/ageing-ireland-living-longer-and-cleanerbrings-its-own-problems-1.2928267 (Erişim: 05.02.2018).

Tüik, (2017). İstatistiklerle Yaşlılar. Yayın No: 24644.

United Nations (2015). Department of Economic and Social Affairs Population Division: World Population Ageing 1950-2050.

Wallace, R. \& Wolf, A. (2012). Çağdaş Sosyoloji Kuramları Klasik Geleneğin İyileştirilmesi. Mehmet Rami Ayas ve Leyla Elburuz (Çev.). Ankara: DoğuBatı Yayınları.

Weber, M. (2011). Protestan Ahlakı ve Kapitalizmin Ruhu. Mehmet Köktürk (Çev.). Ankara: Bilgesu.

Withnall, A. (2004). Older Learners: Challenging the Myths, in Withnal. A., McGivney, V. and Soulsby, J. (eds.). Older people learning - myths and realities, içinde sf. 85-100, Leicester: NIACE.

Withnall, A. (2010). Improving Learning in Later Life. London: Routladge.

Yıldırım, C. (2016). Bilim Felsefesi. İstanbul: Remzi Kitabevi. 